\title{
ATOMIC ENERGY COMMISSION
}

\section{BUREAU OF MINES}

\author{
US BM
}

PROCESS HEAT REACTOR PROGRAM

\section{QUARTERLY PROGRESS REPORT}

February 1, 1964 to April 30, 1964
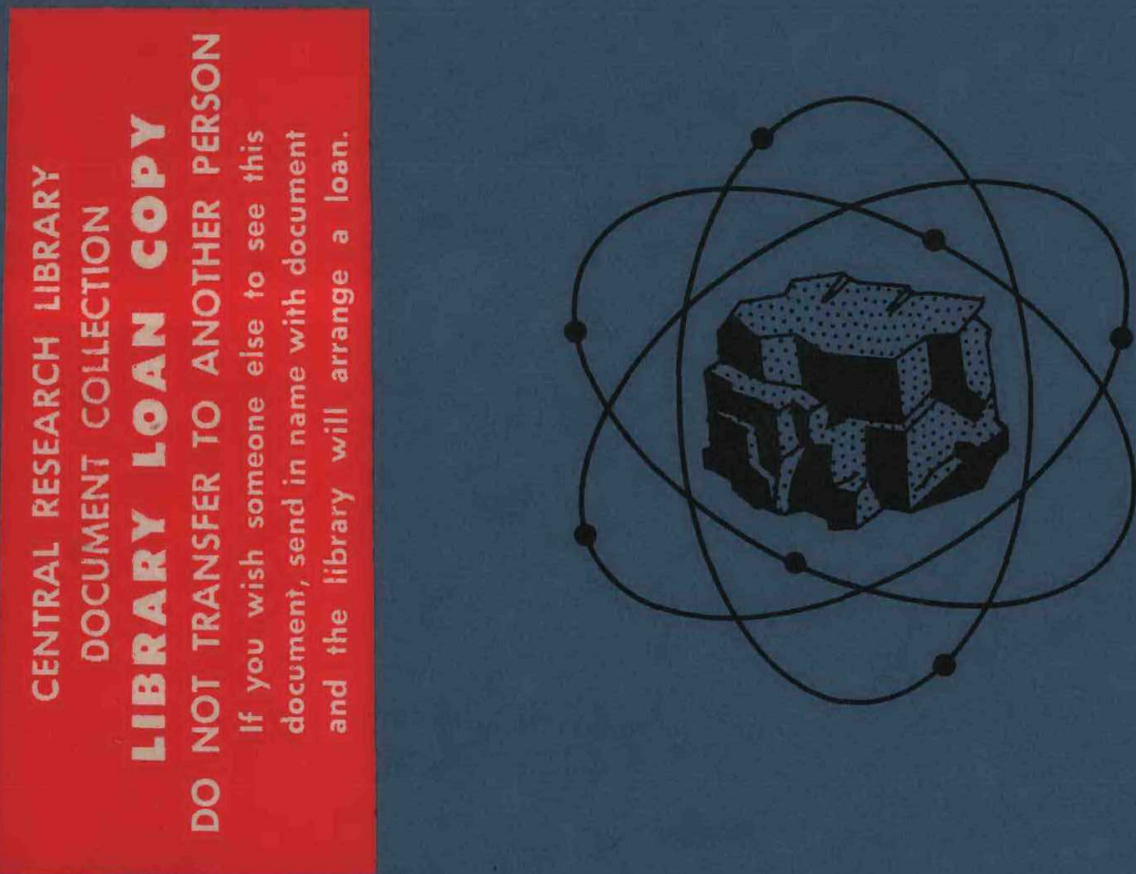

UNITED STATES DEPARTMENT OF THE INTERIOR BUREAU OF MINES

MORGANTOWN COAL RESEARCH CENTER

Morgantown, West Virginia 


\section{DISCLAIMER}

This report was prepared as an account of work sponsored by an agency of the United States Government. Neither the United States Government nor any agency Thereof, nor any of their employees, makes any warranty, express or implied, or assumes any legal liability or responsibility for the accuracy, completeness, or usefulness of any information, apparatus, product, or process disclosed, or represents that its use would not infringe privately owned rights. Reference herein to any specific commercial product, process, or service by trade name, trademark, manufacturer, or otherwise does not necessarily constitute or imply its endorsement, recommendation, or favoring by the United States Government or any agency thereof. The views and opinions of authors expressed herein do not necessarily state or reflect those of the United States Government or any agency thereof. 


\section{DISCLAIMER}

Portions of this document may be illegible in electronic image products. Images are produced from the best available original document. 
Work was continued on the development of a process for the gasification of bituminous coal with heat from a nuclear reactor. Major objectives of the project are: (1) Develop and test components for a gas-cooled reactor system that can heat gases to $2,000^{\circ}=2,500^{\circ} \mathrm{F}$; (2) investigate coal gasification methods compatible with this system; and (3) develop an exchanger that can utilize high-temperature beat to gasify coal or heat chemical process streams.

Development of a high-temperature heat system and study of gasification methods were reported previously. During the past year, work was concentrated on the design, construction and installation of a fluidized-bed gasifier in the high-temperature heat system.

Design of the fluidized-bed gasifier was based on information obtained from laboratory and pilotmscale gasifiers. The gasification chamber, a length of 6-inch, schedule 80 stainless steel pipe, is fitted with ten 1/2-inch Hastelloy-X tubes running lengthwise。 Hot helium flowing through the 1/2-inch tubes provides heat for the gasification of the steam-fluidized char in the 6-inch pipe. Helium leaving the gasifier generates the superheated steam required for gasification. Fabrication and installation of the gasifier was completed and shakedown runs started.

In the gasifier, the heat-exchanger tubes will be heated to $1,900^{\circ} \mathrm{F}$ in a mixture of corrosive gases, including $\mathrm{H}_{2}, \mathrm{CO}, \mathrm{CO}_{2}$, $\mathrm{H}_{2} \mathrm{~S}$ and steam. Few of the well-establisbed alloys can withstand this service, but some of the newer high-temperature alloys may be suitable. Several of them are being evaluated in an environmental testing apparatus. This unit provides controlled temperature of sample tubes and an atmosphere identical to that in the gasifier. Chemical and metallurgical analyses of the alloy specimens will be made aftex the tubes have been tested.

\section{PART II. - GAS SOL LDS SUSPENSIONS AS HEAT-TRANSFER MEDIA}

Heat transfer from the gas coolant is an important factor in the u.se of a gasmcooled nuclear reactor to supply heat for coal gasification and other chemical processes. Theoretically, solid-in-gas suspensions would have greater heat capacity than pure gas. Work was continued on investigating the feasibility of adding finely divided solid particles to the gas to improve heat transport characteristics. 
Most of the work on this project has involved the use of nucleargrade graphite in an inert gas because of compatibility with a reactor. At solids loadings of up to 1 pound per pound of gas, heat transfer coefficients were slightly higher, but corresponding increases in the power required to circulate the suspension prevented significant gains in heat transport economy. However, solids deposition on the cold walls of the heat exchanger prevented an accurate evaluation of the heat transfer capability of suspensions.

Work was begun on a new test 1oop equipped to extend the range of velocities and solid-to-gas ratios and provide better measurement of the energy required to circulate gas-solids suspensions. Researchers working with other two-phase systems have reported that deposition can be significantly reduced by operating at higher velocities and greater solid-to-gas ratios. After first studying the energy required to circulate suspensions, the system later will be used in studies to prevent graphite deposition.

Measuring the mass flow of solids in a suspension has handicapped researchers in this field because no meters were available for this purpose. As part of this project such a meter was developed. The device consists of a target at the end of a cantilevered metal strip to which is attached a silicon semiconductor strain gage. Gas and solids strike the target and deflect the strip, and the resulting strain is measured by the strain gage. The meter has performed satisfactorily in tests with nitrogen-graphite suspensions up to 0.86 pounds per cubic foot and with coal-gas mixtures up to 25 pounds per cubic foot. Development of the two-phase flowmeter was discussed in a paper presented at the Winter Annual Meeting of the ASME.

\section{PART III。 - TURBOMACHINERY}

Work was initiated on the development of turbomachinery with hydrodynamic, gas-Iubricated bearings. Bearings of this type offer promise for high-temperature operation without the problems usually presented by mechanical seals.

Mechanical Technology Inc. (MTI) was contracted to design and construct a 10-hp helium compressor with hydrodynamic, gas-lubricated bearings. Designed to circulate $1,000^{\circ}-\mathrm{F}$ helium, this compressor is a prototype circulator for a high-temperature, gas-cooled reactor. Performance tests in May, 1963, showed the unit to more than meet design requirements.

MII also designed and began construction of a helium turbocompressor with hydrodynamic gas-lubricated bearings. This unit is a prototype of (I) a closed-cycle gas turbine that could operate on 
coal or nuclear heat; and (2) a turbocirculator for a gas-cooled nuclear reactor. The unit is designed for 10,000 pounds of helium per hour at turbine inlet temperatures of $1,400^{\circ}$ to $1,600^{\circ} \mathrm{F}$. As currently developed, the turbocompressor initially will be operated on a self-sustaining basis with no power takeoff. Fnergy furnished by the turbine in excess of about $150 \mathrm{hp}$ required for the compressor will be dissipated by induced pressure drops. MTI also began construction of a loop to test the turbocompressor. The turbocompressor is to be operated in conjunction with the high-temperature loop to evaluate closed-cycle gas turbines (Brayton cycle) as auxiliary power generators for space. This test also will provide information needed to select the best working fluid for a closed-cycle, coalburning gas turbine. 


\author{
REPORT OF PROGRESS \\ February 1 to April 30, 1964
}

PART I. - USE OF NUCLEAR HEAT FOR COAL GASIFICATION

Introduction

Estimates indicated the cost of producing synthesis gas from coal might be appreciably reduced if heat for gasification is supplied by a nuclear reactor. $(1, \underline{2}, \underline{3})$ I Nuclear heat also appeared attractive for chemical processing in other fields. Accordingly, the Atomic Energy Commission and the Bureau of Mipes began a program to develop a nuclear heat process for gasification.(4) Known as the Process Heat Reactor Program, the AEC - BuMines effort had two major objectives. The first objective was to develop and test components for a nuclear reactor that can heat a circulating gas to $2,200^{\circ}-2,500^{\circ} \mathrm{F}$. The second objective was to develop an exchanger capable of transferring this heat to process streams.(5)

An indirect cycle (with helium as the heat-transfer medium) was chosen for initial development of a high-temperature process heat system having simulated or prototype equipment useful for establishing feasibility. $(6,7)$ The Bureau constructed two pilot-scale heliumrecycle systems in which a vessel containing inductively heated graphite spheres simulated a nuclear reactor. The first loop, operating at atmospheric pressure, furnished essential experience in heating graphite spheres by induction and information on the transfer of heat from the spheres to the recycled helium. The second loop, operated at 250 psig, was equipped with an improved reactor and a special compressor to recycle $1,000^{\circ} \mathrm{F}^{2}$-helium. $(7,8)$ This system commonly is referred to as the helium recycle or ISR system. After considerable development work, particularly on the helium compressor and the simulated nuclear reactor, sustained operability of this system was demonstrated by a continuous 1,000 -hour test in which the reactor heated helium to $2,500^{\circ} \mathrm{F} .(9,12)$ Concurrent with these developments, the Bureau investigated gasification methods that would be compatible with the high-temperature process heat system. Of three methods studied $(10,11)$, fuidized bed gasification appeared most feasible?/, so a gasifier of this type was designed and constructed. Tests with the simulated nuclear gasification system are in progress.

\footnotetext{
1 Underlined numbers in parentheses refer to items in the bibliography at the end of this report.

2) M. W. Kellogg Co. A Technical and Economic Evaluation of SolidFuel Gasification Using Nuclear Heat. Nov. 30, 1962.
} 


\section{PSIG STMULATED NUCLEAR COAL GASIFICATION SYSTEM}

The simulated nuclear gasification system was completed. Figure 1 is a flowsheet of the system; figure 2 is a sketch of the gasifier. Helium heated to $2,200^{\circ} \mathrm{F}$ in the ISR supplies heat for the steam gasification of char, a bituminous coal pretreated to destroy its caking properties. Figure 3 shows the 6-inch diameter gasification chamber being lowered into the gasifier. A view of the complete installation is shown in figure 4. All electrical, instrumentation, and insulation work was completed and shakedown tests begun.

\section{Plans for Future Work}

The system will be operated to evaluate fluidized-bed gasification with heat from high-temperature helium.

\section{ENVIRONMENTAL TESTING OF HIGH-TEMPERATURE AILOYS}

In the helium-heated gasifier of the simulated nuclear system, the heat exchange tubes are exposed to $1_{\Omega} 800^{\circ}-F^{\prime}$ temperatures and corrosive gases, mainly $\mathrm{H}_{2}, \mathrm{CO}_{3} \mathrm{CO}_{2}, \mathrm{H}_{2} \mathrm{~S}$, and steam. Few, if any, of the wellestablished alloys will withstand this service. Some of the newer hightemperature alloys, however, may be suitable. Some of these newer alloys are being evaluated by exposing them to gasification conditions in the apparatus of figures 5 and 6. Char fluidized with superheated steam is gasified outside the tube. Casification heat is supplied by resistance heaters in a helium atmosphere inside the tubes. Type-310 stainless steel, Hastelloy-X, Raonel 333, Raonel 600, Inconel 702, and Incoloy 804 have been procured for testing. Compositions of these alloys are given in Table 1. Other alloys may be obtained later. For example, we eventually hope to test new heat exchanger tubes developed by the General Electric Company. This material reportedly can operate above $2,000^{\circ} \mathrm{F}$.

Tests were begun in February, 1964. Operating temperature was $1,800^{\circ} \mathrm{F}$ (gas) and the operating pressure was 3 psig. A typical gas analysis was: $\mathrm{H}_{2}-58.1 ; \mathrm{CO}-25.2 ; \mathrm{CO}_{2}-13.2 ; \mathrm{CH}_{4}-1.0 ; \mathrm{N}_{2}-1.9$; $\mathrm{O}_{2}-.6$

The outside surfaces (exposed to the gasification atmosphere) of the internally heated specimens are maintained at approximately $1,960^{\circ} \mathrm{F}$ to provide temperatures of $1,800^{\circ} \mathrm{F}$ in the environmental atmosphere. After about 30 hours at $1,900^{\circ} \mathrm{F}$ or higher, no severe corrosion was apparent on the outside of the tubes or on the wall of the type-310 stainless steel reactor. 


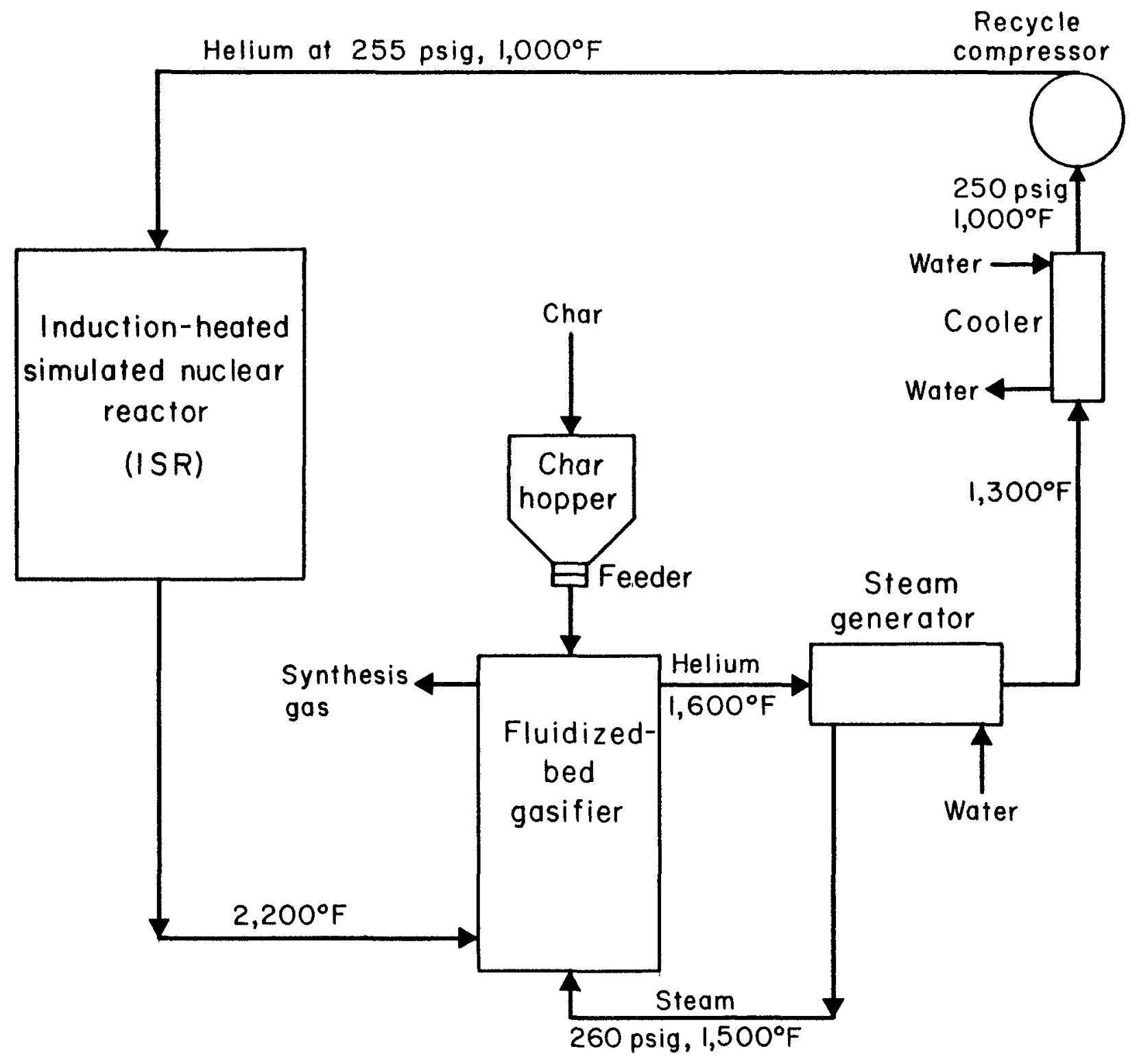

FIGURE 1. - Flowsheet for ISR System With Fluidized-Bed Coal Gasifier. 


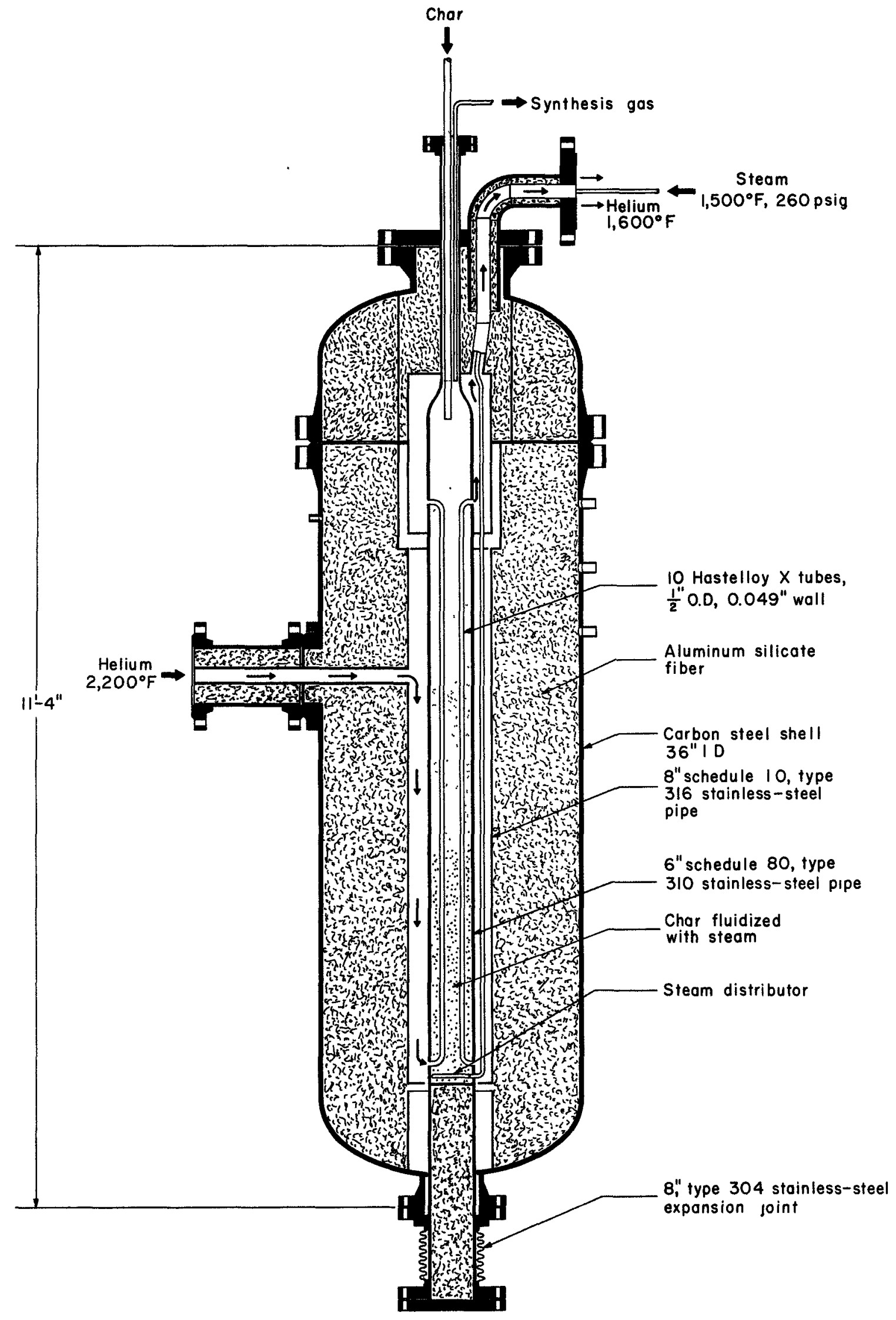

FIGURE 2. - Fluidized-Bed Coal Gasifier for ISR System. 


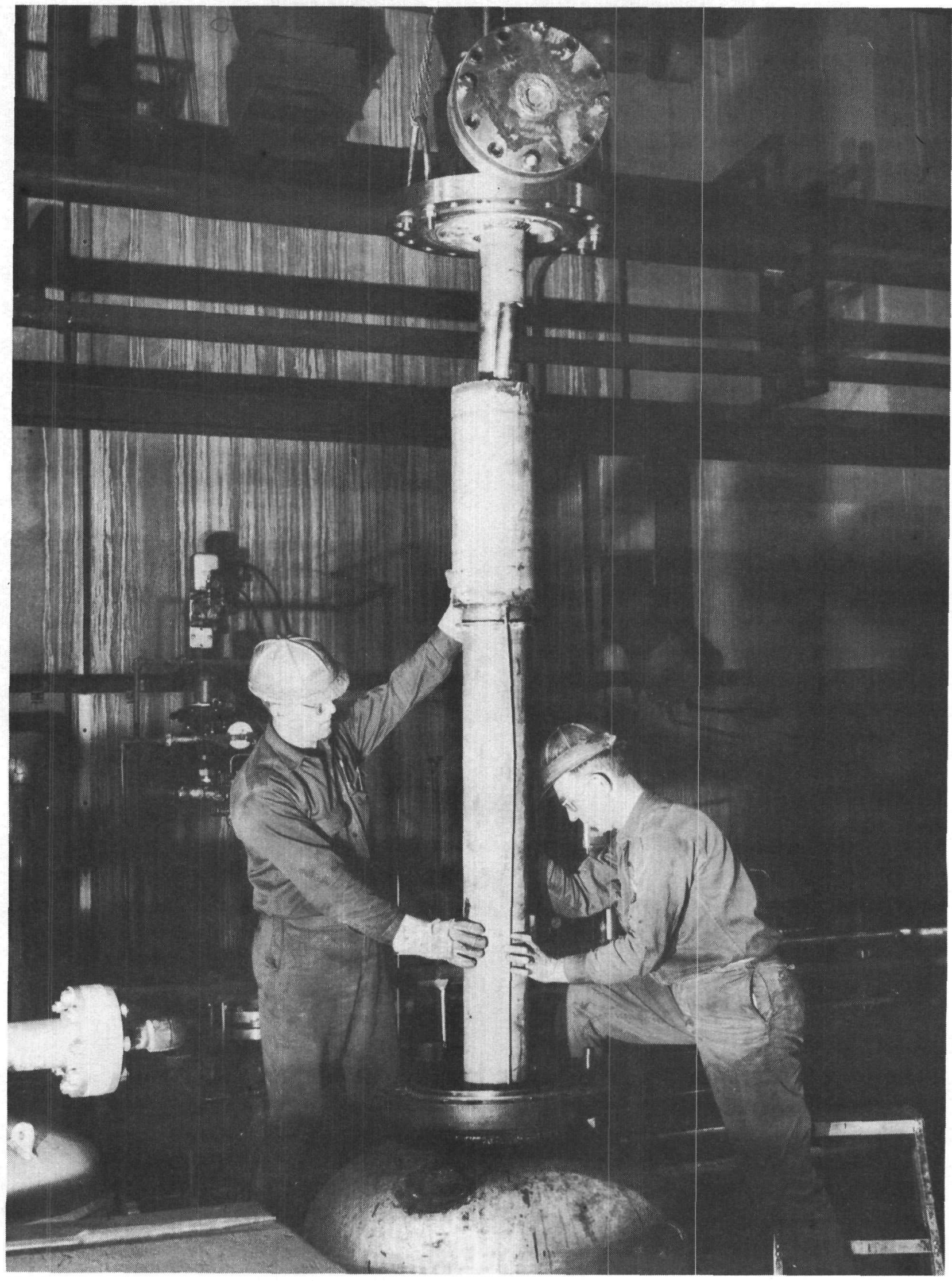

FIGURE 3. - Gasification Chamber Being Lowered Into Gasifier. 


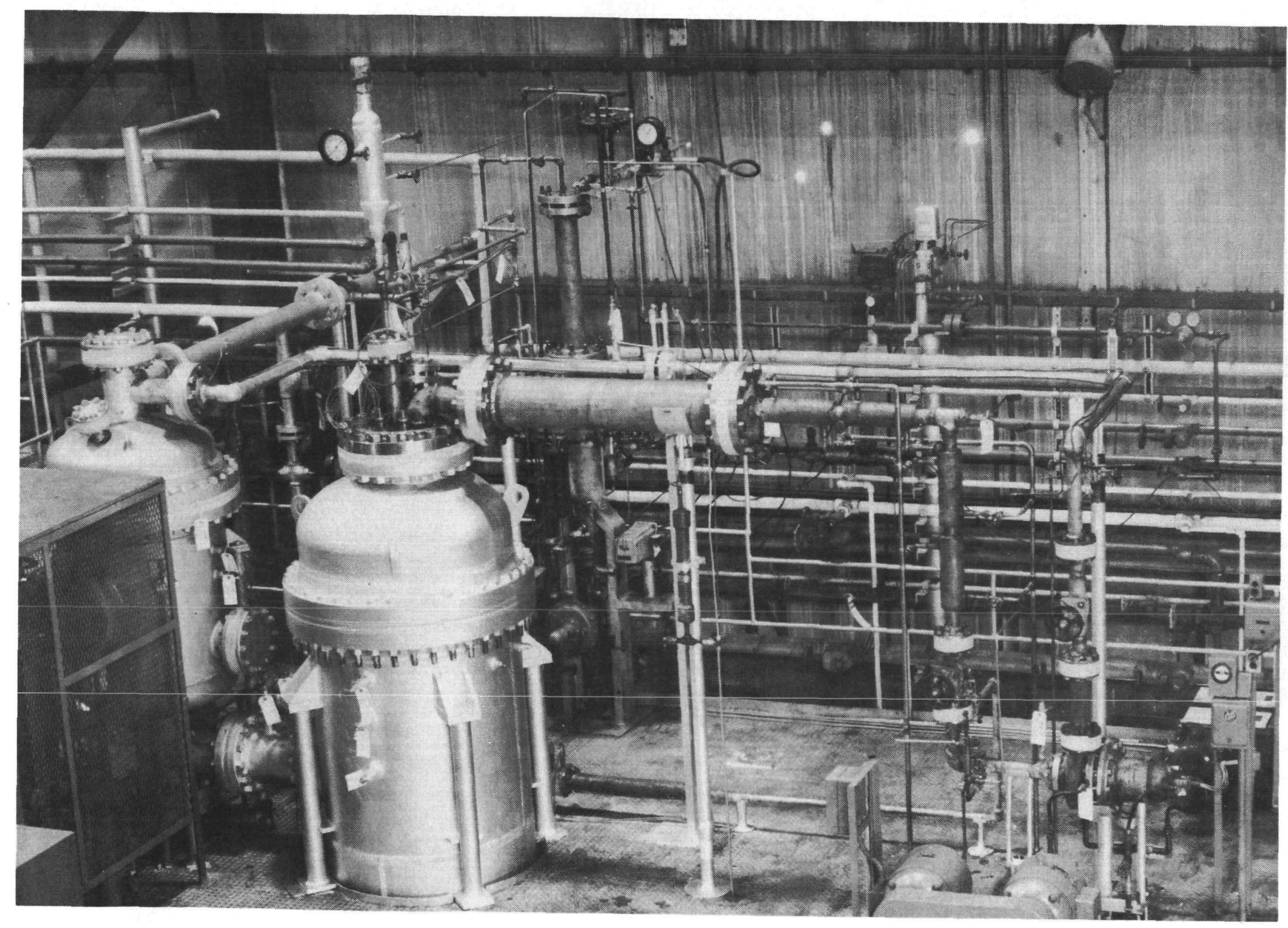

FIGURE 4. - ISR System With Fluidized-Bed Coal Gasifier. 

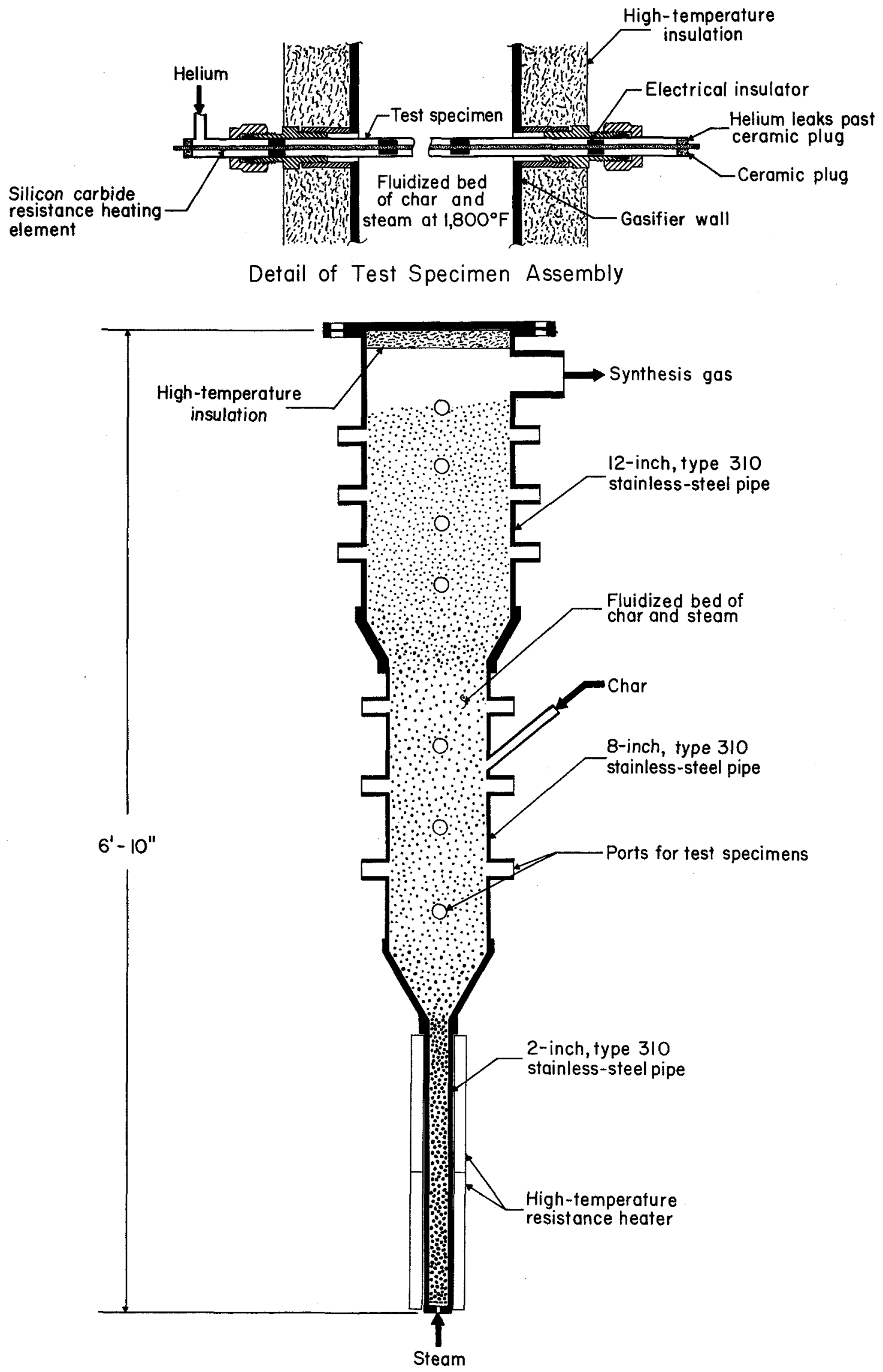

FIGURE 5. - Environmental Testing Apparatus. 


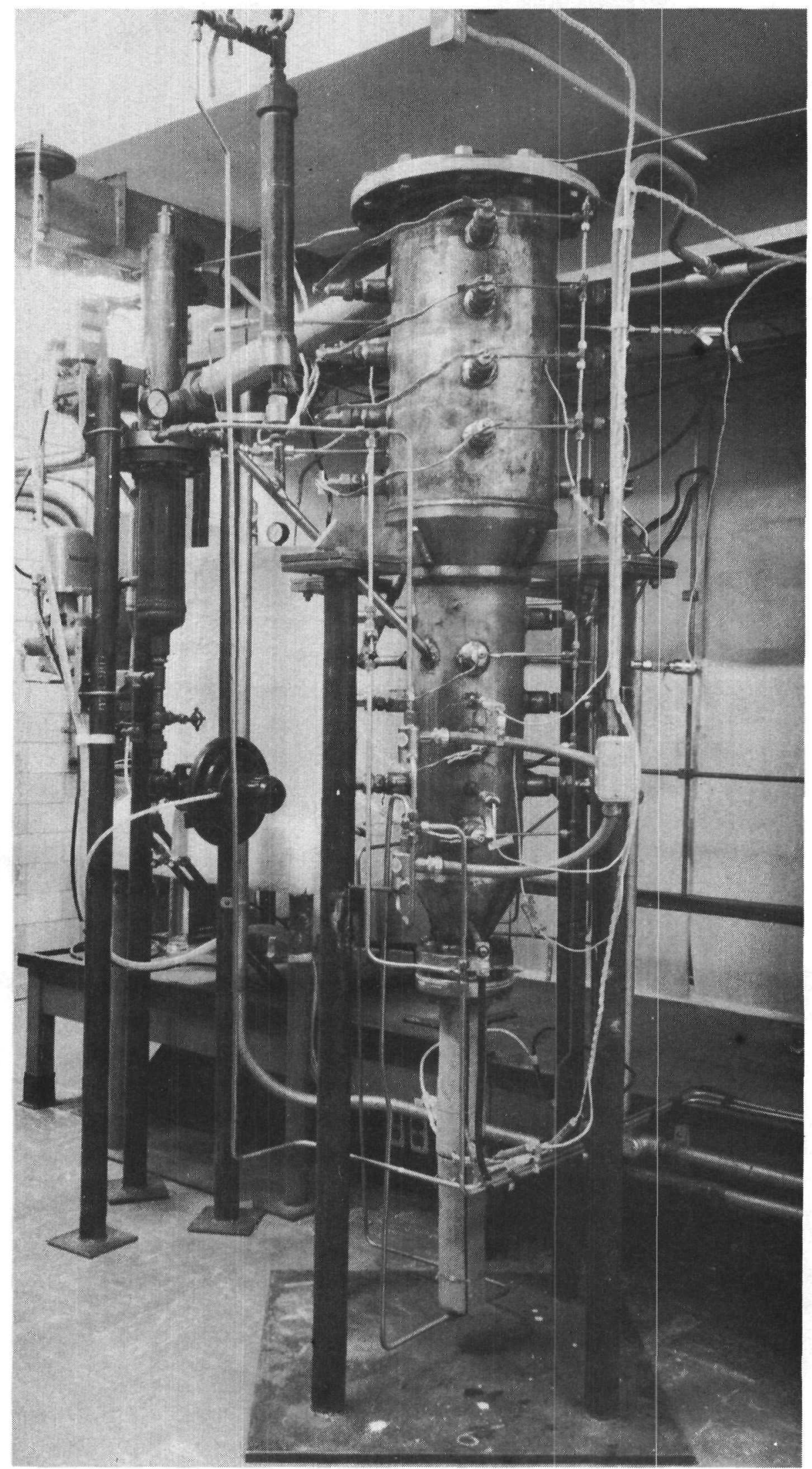

FIGURE 6. - View of Environmental Testing Apparatus. 
Table 1. - Composition of alloys subject to

\begin{tabular}{|c|c|c|c|c|c|c|}
\hline & $\begin{array}{c}\text { Type } 310 \\
\text { ss }\end{array}$ & $\begin{array}{c}\text { Hastel- } \\
\text { loy-X }\end{array}$ & $\begin{array}{c}\text { Raone1 } \\
333 \\
\end{array}$ & $\begin{array}{c}\begin{array}{c}\text { RaoneI } \\
600\end{array} \\
\end{array}$ & $\begin{array}{c}\text { Inconel } \\
702\end{array}$ & $\begin{array}{c}\text { Incoloy } \\
804\end{array}$ \\
\hline $\mathrm{Ni}$ & $19-22 \%$ & $48-85 \%$ & $44-47 \%$ & $75.0 \%$ & $73.8-78.6 \%$ & $42.6 \%$ \\
\hline $\mathrm{Fe}$ & $48-53$ & 20.0 & 18.0 & 8.0 & 2.0 & 25.4 \\
\hline $\mathrm{Cr}$ & $24-26$ & 22.0 & $24-27$ & 15.0 & $14-17$ & 29.3 \\
\hline C & .25 & .15 & .08 & .05 & .1 & .06 \\
\hline Mo & & 9.0 & $2.5-4$ & & & \\
\hline Mn & 2.00 & & 2.0 & .7 & 1.0 & .85 \\
\hline Si & 1.50 & & $.75-1.5$ & $\cdot 3$ & .7 & .50 \\
\hline W & & & $2.5-4$ & & & \\
\hline Co & & & $2.5-4$ & & & \\
\hline $\mathrm{Cu}$ & & & .5 & & .5 & .40 \\
\hline$P$ & & & .03 & .1 & & .007 \\
\hline S & & & .03 & .1 & .1 & \\
\hline Sn & & & .025 & & & \\
\hline $\mathrm{Pb}$ & & & .025 & & & \\
\hline$T i$ & & & & & $25-1.0$ & .40 \\
\hline Al & & & & & $2.75-3.75$ & .25 \\
\hline
\end{tabular}


A major problem has been globar failures caused by deformation of the test specimens, so expansion bellows are being installed at one end of each specimen.

Plans for Future Work

We will continue our efforts to make the environmental testing apparatus capable of sustained operation. 
PART II。 - GAS-SOLIDS SUSPENSIONS AS HEAT TRANSFFR MEDIA

Introduction

Suspensions of finely divided solids in gas appear promising as a coolant for a nuclear reactor and as the working fluid in a closed-cycle gas turbine fired by nuclear or fossil fuels. Helium-graphite suspensions, for example, reportedly give higher film coefficients of heat transfer and greater heat transport per unit volume.3/ Moreover, if the solids absorb heat, the compression and expansion of a suspension might be nearly isothermal, thus reducing compression power and increasing expansion power.

The Bureau, at the request of the $\mathrm{AEC}$, has been investigating the potential advantages of gas-solids suspensions. Objectives of this program were to determine (1) the problems involved in continuously circulating suspensions in a closed loop, including erosion of equipment; and (2) the energy required to transfer heat with suspensions.

Several test systems built and operated by the Bureau have supplied considerable information on suspensions. Suspensions could be circulated satisfactorily, for example, and equipment erosion was negligible. Deposition of graphite gave the most trouble, particularly on the cold surfaces of heat exchangers. At low solids concentrations and low flow rates, before graphite deposited on the inside walls, slightly less energy was required to circulate suspensions per unit of heat transported than was required for helium. Deposition could be reduced by circulating the suspension at higher velocities, but the additional power required to do so more than off set any advantage in heat transfer. $(13,14)$ Graphite deposition and velocity limitations on the test equipment have so far precluded positive evaluation. Ffforts are being made to overcome these problems.

THE ENERGY REQUIRED TO CIRCULATTE GAS-SOLIDS SUSPENSIONS

In previous tests, considerable bearing trouble was experienced with the "canned" circulators. $\mathrm{Al}_{\mathrm{sO}}$, the energy input could not be accurately measured so it was difficult to make a positive evaluation of the energy required to circulate suspensions. Moreover, the capacity of the compressors limited the gas velocities to about $75 \mathrm{ft} / \mathrm{sec}$ and graphite concentrations to approximately I lb/cu ft. Therefore, we are building a new loop equipped with a compressor designed to provide accurate measurement of energy and able to circulate up to 5-10 pounds of graphite per cubic foot of gas.

$3]$ Gas Suspension Task III Final Report, BAW-2101, The Babcock \& Wilcox Company。 JuIy 3I, 1960。 
Figure 7 is a sketch of this loop. Constructed of 1-inch OD stainless steel tubing, it includes solids-charging and fllow-sampling sections. The solids-charging section consists of a removable section of the loop. The flow-sampling section is a length of tubing with two removable, fast-acting ( 0.05 seconds closing time) valves on each end. It will be used to obtain "grab" samples for direct measurement of solids concentration. Results from the flow sampler will be used to calibrate a Venturi-type gas flowmeter and a gas-solids flowmeter (described in a later section of this report).

The compressor, figure 8 , is driven by a hydraulic motor driven by a hydraulic pump powered by a 7-1/2 hor sepower electric motor. speed of the hydraulic motor can be varied between 0 and 14,500 rpm with the torque relatively constant over the entire range. A straingage-type sensor on the drive shaft measures speed and torque (power).

The compressor shafit is equipped with a gas-buffered labyrinth seal in an effort to prevent the suspension from leaking. The bearings, which are outside the compressor housing, are cooled by gas flowing through the hollow shaft, the inboard bearing receiving additional cooling from a water coil outside the compressor housing.

All materials and equipment, including the compressor, have been ordered for the loop.

Plans for Future Work

We will proceed to build the new system and use it to investigate the energy required to circulate gasmsolids suspensions.

\section{PREVENIION OF GRAPHITE DEPOSITION}

During tests with nitrogen graphite suspensions, tubing inmediately downstream from a probe inserted to measure suspension flow remained relatively clean. Thinking that a device similar to this probe might reduce or eliminate deposition. a heat exchanger was constructed with several small cones suspended in the center of the pipe.

Results from this exchanger indicated that the cones reduced but did not eliminate deposition, This suggests that the geometry of the exchanger and/or velocity influence deposition.

Figure 9 shows a section of tubing that was cut open after a test run. Part of this section had been receiving heat, part had been open to the air and subject to natural cooling. The heated section remained clean, whereas the cooled section was coated with graphite, 


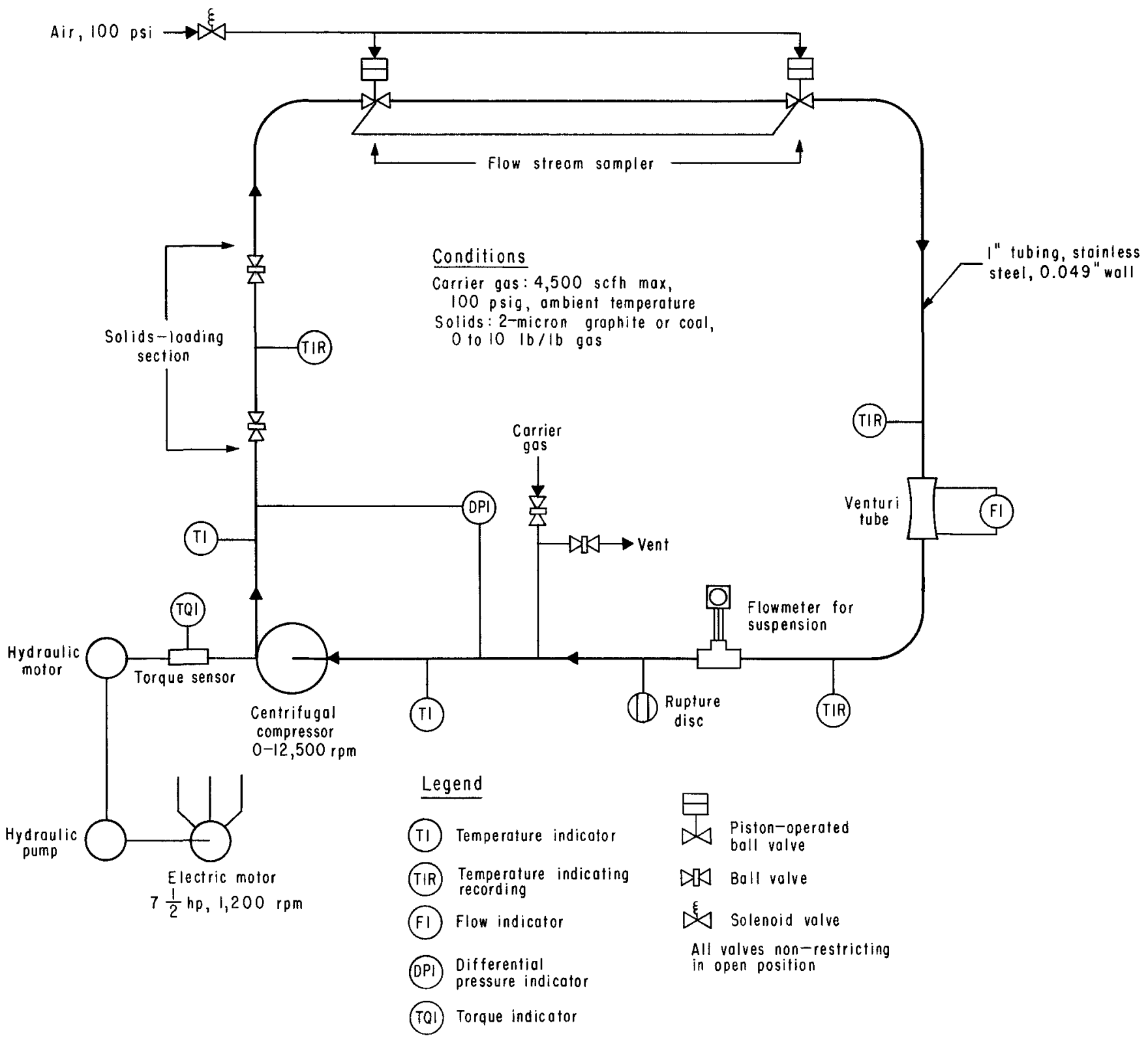

FIGURE 7. - Apparatus Used To Determine the Energy Required To Circulate Gas-Solids Suspensions. 


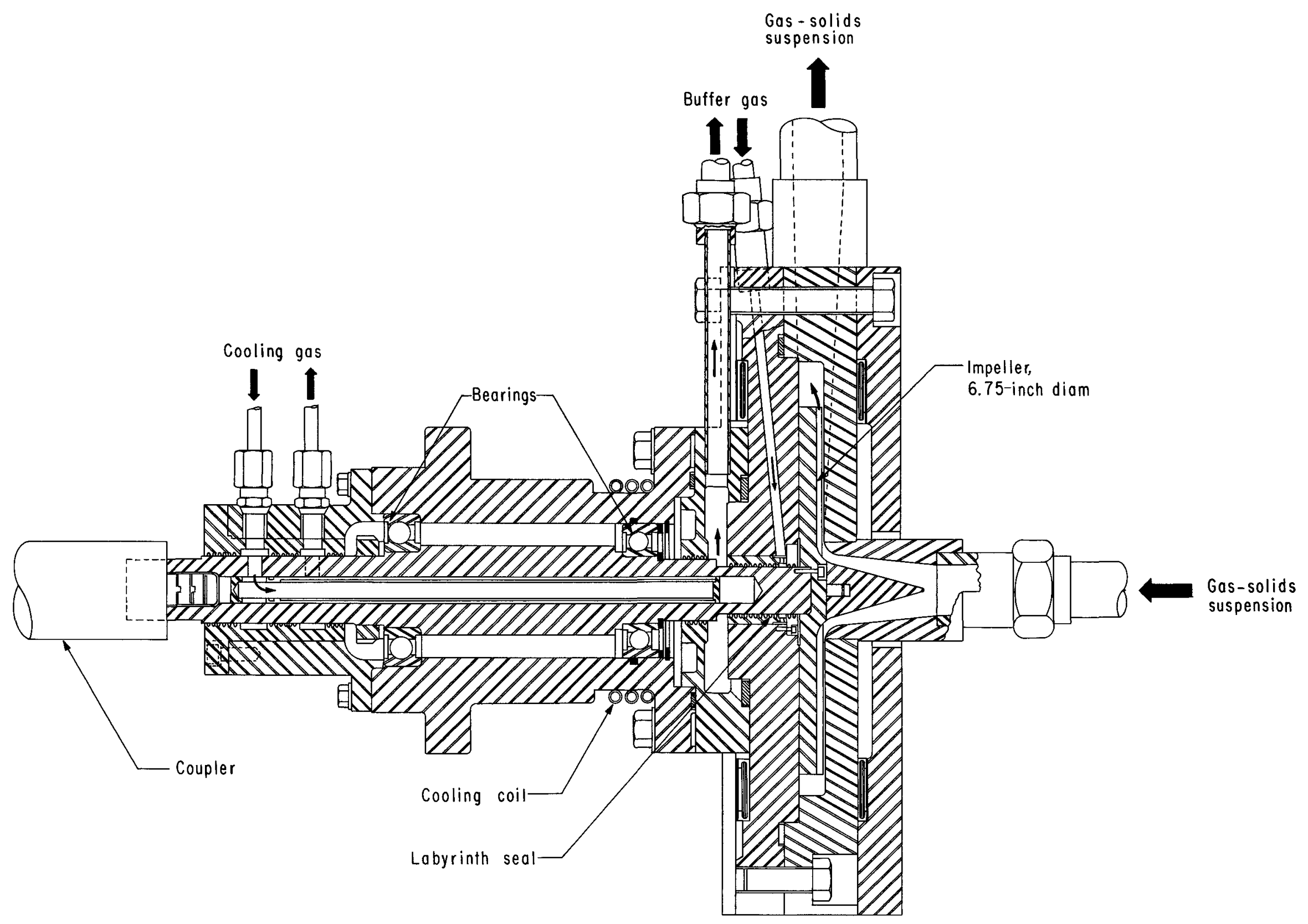

FIGURE 8. - Compressor for Gas-Solids Suspensions. 


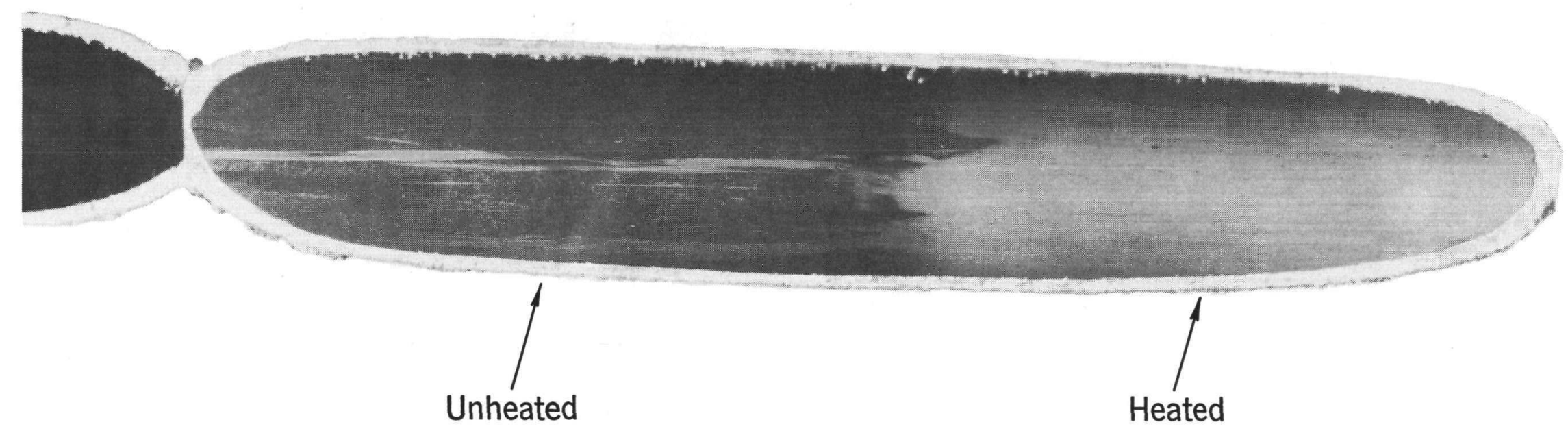

FIGURE 9. - Graphite Did Not Deposit on Heated Surface. 
demonstrating again that graphite does not deposit in heated sections but does deposit in cooled sections.

\section{Plans for Future Work}

As time permits we will continue to try different types of heat exchangers in an attempt to eliminate deposition.

\section{MEPER FOR MEASURING THE FLOW OF SOLIDS IN GAS-SOLIDS SUSPENSIONS}

One of the problems associated with the investigation of gassolids suspensions was the lack of a reliable instrument to measure the flow of the finely divided solids. Our interest in gas-solids suspensions and pneumatic transport of coal led to the development of such a device here at Morgantown. The device is essentialiy a target at the end of a cantilevered metal strip to which a strain gage is attached. Gas and solids strike the target and deflect the strip, the resulting strain being detected by the gage and relayed to an indicator. (15)

In recent weeks, the meter has been used to measure the flowrate of powdered coal in suspension. (In this application, foil strain gages, gage factor of 2.0 , are used and this target is a 1/8-inch rod, figure 10.)

Figure 11 shows meter response as a function of the flowrate of powdered coal. The upper graph represents tests at 0 to 100 psig, the other shows data from tests at 200 psig. After enough data are obtained, the result should be a family of smooth curves, each representing a specific gas flowrate.

Deposition or erosion of the target was considered a possible source of trouble since either might change the aerodynamic characteristics of the target, thereby causing errors in the calibration of the meter. After 12 hours in the coal-transport Iine, however, there was no erosion and negligible deposition of coal (figure 12).

Dr. R。I. Peskin, Rutgers University, has agreed to evaluate our two-phase flowmeter. Dr. Peskin is conducting research on the heattransfer coefficients of gas-solids suspensions (for the AEC) in a once-through system using glass beads entrained in a gas. Tests with the meter in this system should provide an excellent evaluation since the solids and gas flowrates can be measured very accurately. A meter is being modified for installation in Dr. Peskin's system. 


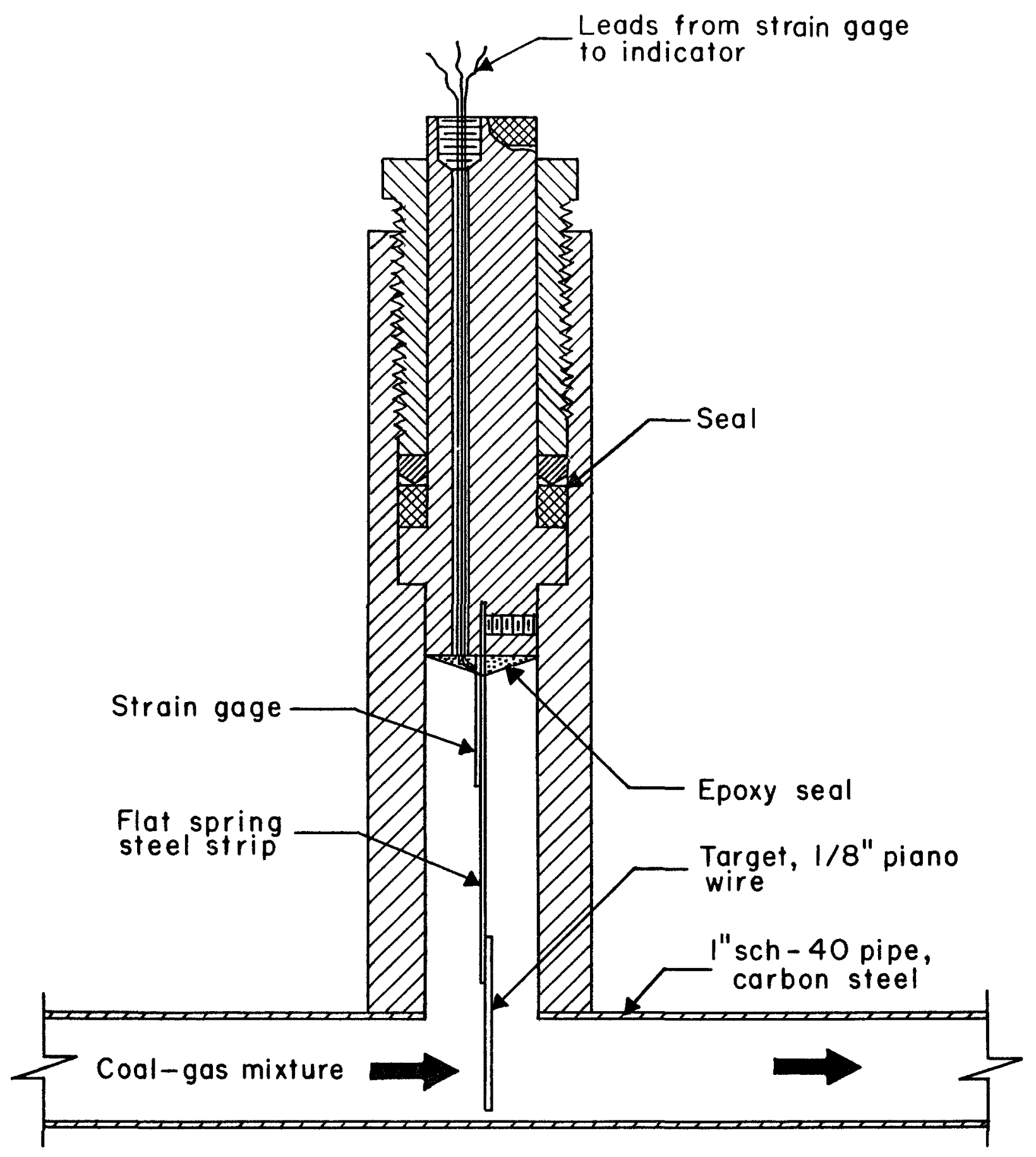

FIGURE 10. - Gas-Solids Flow Meter in Coal-Transport Line. 

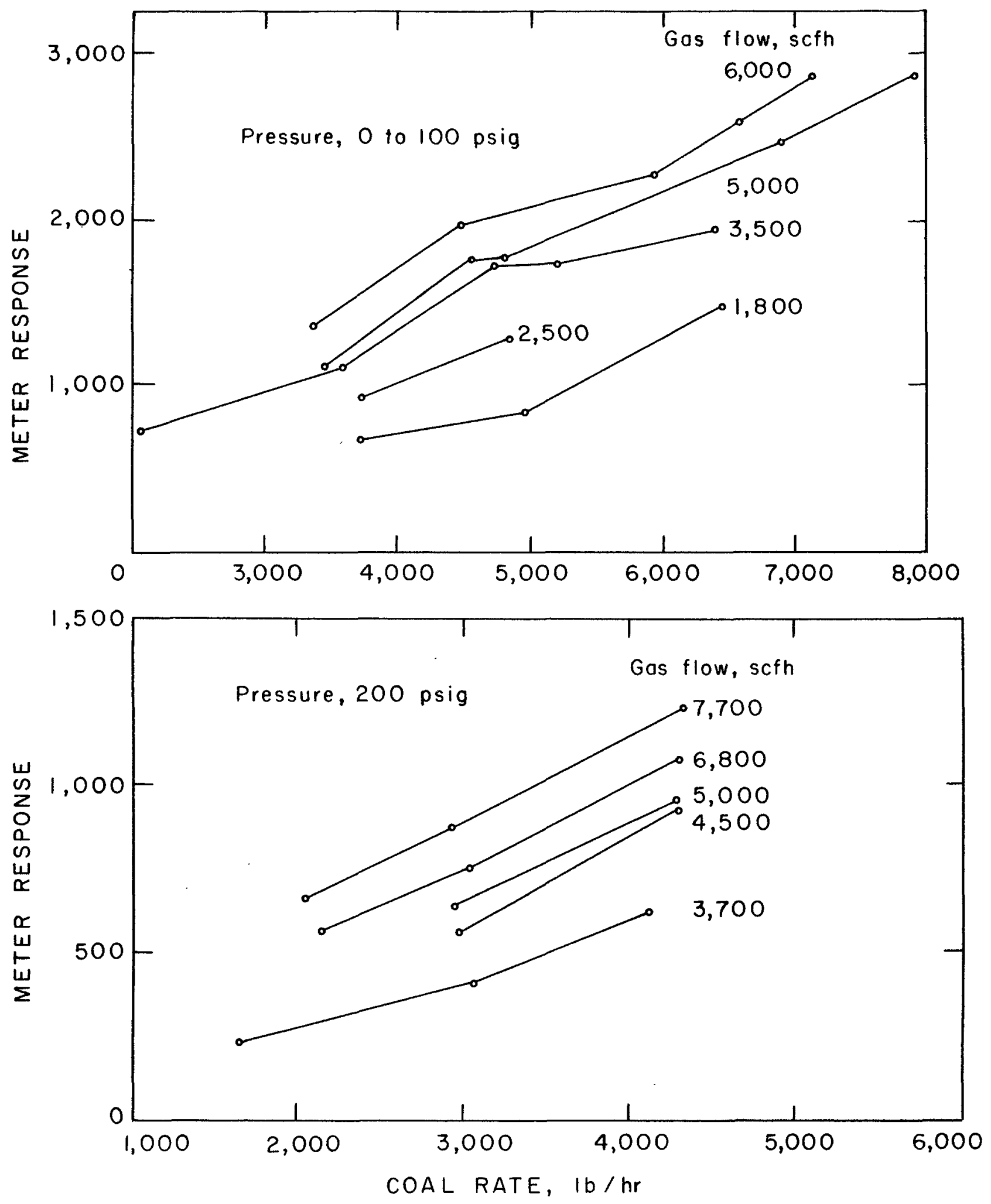

FIGURE 11.- Meter Response To Flow of Coal-Gas Mixtures. 


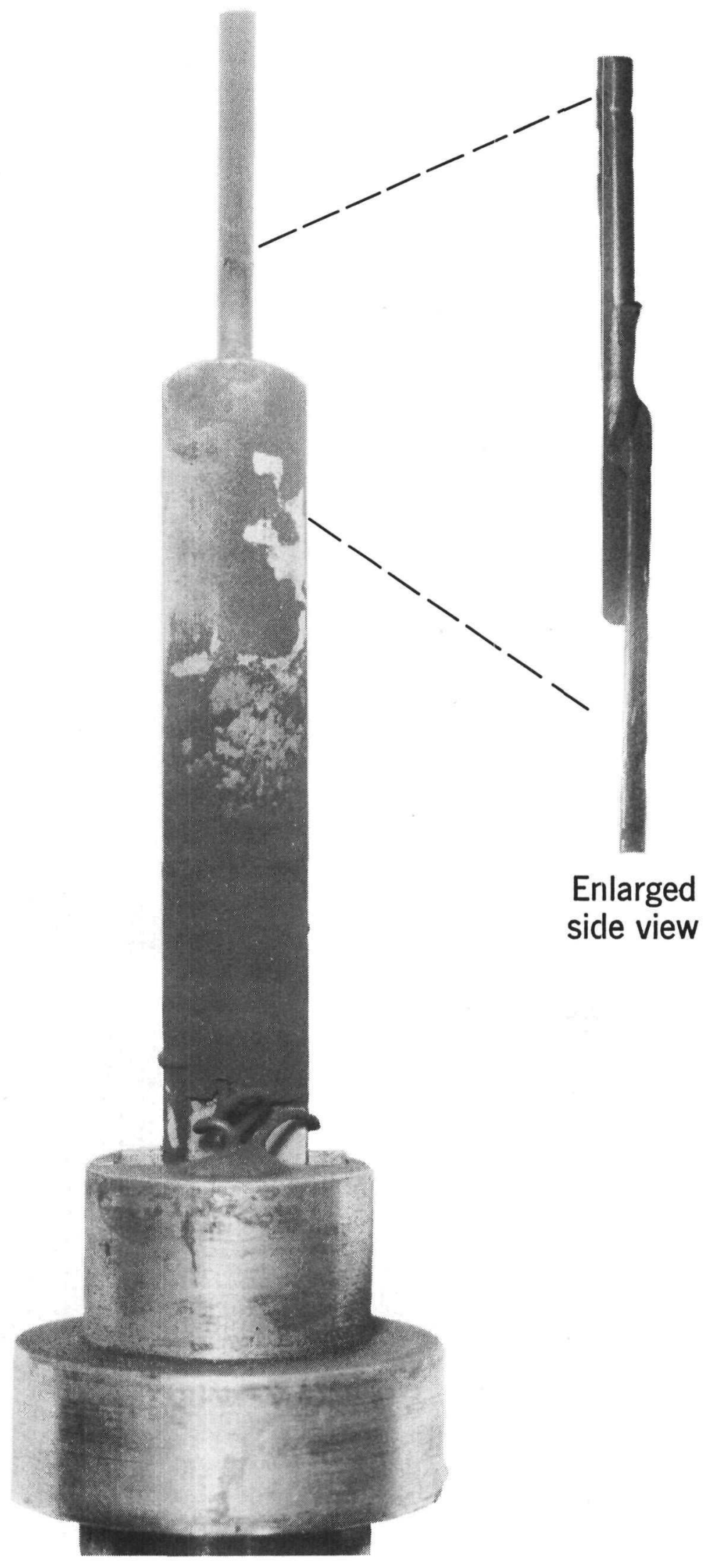

FIGURE 12. - Flowmeter Probe From Coal-Transport Line After 12 Hours. 
Plans for Future Work

We plan to continue to evaluate the meter for measuring the flow of coal in pneumatic transport and prepare the modified meter for shipment to Rutgers University. 
PART III. - TURBOMACHINERY

Introduction

Both the AEC and BuMines are developing processes that require turbomachinery for gases at high temperatures and pressures. of particular interest are: (I) circulators for gas coolants in high-temperature nuclear reactors; (2) circulators for hot gases produced in various coalconversion processes; and (3) turbocompressors to serve as prototype closed-cycle gas turbines fired by nuclear heat or coal. In addition to extreme conditions of temperature and pressure, gases required in these applications may be toxic, combustible, or radioactive. As a result, turbomachinery for this service must be leaktight. A few types of commercial units are available for this type of service, but most have mechanical seals that often leak or permit contamination of the gas by the lubricants. Turbomachinery with gas-lubricated bearings may be the answer to this problem: Gas bearings do not require mechanical seals and can be hermetically sealed to prevent leaks.

Gas-lubricated bearings are classified as two basic types, hydrostatic and hydrodynamic. In the hydrostatic type, an auxiliary compressor furnishes a pressurized side-stream of the circulating gas to lubricate the bearing. Hydrodynamic bearings, on the other hand, are self-acting-the rotating shaft pressurizes the circulating gas that lubricates the bearing. Hydrodynamic bearings are less complicated because auxiliary pressurizing equipment is not required, thus they appear to be the more attractive type for further development. Accordingly, the AEC and the Bureau are cooperating in the development of turbomachinery equipped with hydrodynamic gas bearings.

\section{CENTRIFUGAL HEL TUM COMPRESSOR WITH GAS-LUBRICATED BEARINGS}

Mechanical Technology Inc. (MII), under contract with the Bureau, designed and constructed a 10-hp helium compressor (circulator) with hydrodynamic, gas-lubricated bearings. Designed to circulate $1,000^{\circ}-\mathrm{F}$ helium, this compressor is a prototype circulator for a high-temperature, gas-cooled reactor. Performance tests in May 1963, showed the unit to more than meet design requirements.4 No further tests have been made with this compressor, but a tentative test program for the unit is being formulated and will be discussed in our next quarterly progress report.

4 Atomic Energy Commission - Bureau of Mines quarterly Report, May 1 to July 31, 1963, pp. 10, 11 . 


\section{TURBOCOMPRESSOR WITH GAS-LUBRICATED BEARINGS}

Mechanical Technology Inc, also designed and is fabricating a helium turbocompressor with hydrodynamic gas-lubricated bearings. This unit is a prototype of a closed-cycle gas turbine that could operate on coal or nuclear heat, or a turbocirculator for a gascooled nuclear reactor. The unit is designed for 10,000 pounds of helium per hour at turbine inlet temperatures of $1,400^{\circ}$ to $1,600^{\circ} \mathrm{F}$. As currently developed, the turbocompressor initially will be operated on a self-sustaining basis with no power takeoff. Energy furnished by the turbine in excess of about $150 \mathrm{hp}$ required for the compressor will be dissipated by induced pressure drops.

Fabrication of this unit is progressing. MPI has received the casting for the compressor impeller and the turbine rotor, complete with buckets, and the bearing assembly is essentially complete.

Under contract to the AEC, MTI designed and is constructing a loop to test the turbocompressor and other high-temperature turbomachinery. Initially, a model of the turbocompressor rotor will be tested in a smaller system, with expected bearing loads, rotor dynamics, bearing temperatures and thermal gradients simulated to check the soundness of the bearing design. The turbocompressor will then be installed in the larger loop to evaluate its performance and capability for self-sustained operation. Also, turbine and compressor performance maps will be established and extrapolated to larger power systems. Construction of the large loop is proceeding satisfactorily.

In addition to the program discussed above, MTI proposed (to the $A E C$ and the Bureau) operating tests of the Bureau 's turbocompressor in conjunction with the high-temperature loop to evaluate closed-cycle gas turbines (Brayton cycle) as auxiliary power generators for space. In such a system, molten metals from a nuclear reactor would heat a gas turbine working fluid, probably nitrogen or argon. Consequently, the Bureau has written a change order to MPI instructing them to modify the turbocompressor so it can operate with either nitrogen or argon. The change order was approved, and the work outlined in the change order is proceeding. Such a program will provide information needed to select the best working fluid for a closed-cycle coalburning gas turbine. 


\section{BIBLIOGRAPHY}

1. Katell, Sidney. The Economic Outlook for Pipeline Gas From Coal. Coal Age, v. 63, Sept. 1958, pp. 116-118.

2. Perry, Harry, and J. P. McGee. Process Heat From Nuclear Reactors. Chem. Eng., v. 66, Feb. 23, 1959, pp. 143-146.

3. The M. W. Kellogg Co. A Technical and Economic Evaluation of Solid-Fuel Gasification Using Nuclear Heat. NYO 10,301, RD-62-952, Nov. 30, 1962.

4. McGee, J. P., and Sidney Katell. Possibilities of Using Nuclear Energy for Gasifying Coal. BuMines Inf.Circ.7965, 1960, 11 pp.

5. Browning, S. Co, and J.J.S. Sebastian. Ceramic Heat Exchangers for High-Temperature Heat Transfer From Helium. Ind. and Eng. Chem., v. 53, March 1961, p.191.

6. Dalzell, R. C., and J.P.McGee。 An Indirect-Cycle Nuclear Reactor System to Furnish Process Heat--Engineering and Design Concepts. BuMines Inf. Circ. $7920,1959,16$ pp。

7. McGee, J. P. High-Temperature Systems for Nuclear Process Heat. BuMines Inf. Circ. $7954,1960,18$ pp。

8. McGee, J.P., N. Ho Coates, and G. E. Fasching。 Development of a Simulated High-Temperature Nuclear Loop. BuMines Inf. Circ. 7981, 1960, $17 \mathrm{pp}$.

9. Coates, N. H., J. P. McGee, G。 E。 Fasching, Simulated-Nuclear Reactor System for High-Temperature Process Heat: 1,000-Hour Demonstration Run at $2,500^{\circ} \mathrm{F}$. BuMines Rept。 of Inv.5886, $1961,15 \mathrm{pp}$.

10. Konchesky, J. L., and R.F.Stewart。 Laboratory-Scale Gasification of Coal-Water Slurries in a Metallic-Thabe Coil. BuMines Rept. of Inv. 5704, 1961, 29 pp.

11. Gall, R. I0, R. F。 Stewart, and J。P.McGee, Gasification of coal by Hot Recycled Helium; Laboratory-Scale Tube-Coil Gasifier-Part I. BuMines Rept。 of Inv。5996, 1962, 17 pp.

12. Coates, N. H., S.G. Nordlinger, and J。P. McGee. Centrifugal Compressor for High-Temperature Helium: Performance Characteristics. BuMines Rept。 of Inv。6272, 1963, $17 \mathrm{pp}$. 
13. Abel, W. T., J. P. O'Leary, D. E. Bluman, and J. P. McGee. Experiments With Solid-in-Gas Suspensions as Heat Transport Mediums. BuMines Rept. of Inv. 6255, 1963, 18 pp.

14. Abel, W. T., D. E. Bluman, and J. P. O'Leary. Gas-Solids Suspensions as Heat-Carrying Mediums. Am. Soc. of Mech. Eng., Philadelphia, Pa., Nov. 1963. ASME Paper No. 63-WA-210, $1963,5 \mathrm{pp}$.

15. Gibson, H. G., W. T. Abel, and G. E. Fasching. Meter for Determining Mass Flow of Solids in Multi-Phase Fluids. Multi-Phase Flow Symposium, Am. Soc. of Mech. Eng., Philadelphia, Pa. Nov. 1963. 